\title{
Prototype E-Marketplace Information System Service Provider
}

\author{
Muhaimin Hasanudin ${ }^{1 *}$, Haris $^{2}$, Muhamad Zahruddin ${ }^{3}$, Khozin Yuliana ${ }^{4}$ \\ ${ }^{1,3,4}$ Department of Information Systems, Raharja University Indonesia \\ ${ }^{2}$ Department of Informatics Engineering, Raharja University Indonesia
}

DOI: $\underline{10.36348 / \mathrm{sb} .2019 . \mathrm{v} 05 \mathrm{i} 11.005}$

| Received: 04.11.2019 | Accepted: 11.11.2019| Published: 16.11.2019

*Corresponding author: Muhaimin Hasanudin

\section{Abstract}

The labor service provider sector has a role in efforts to support services to customers. But on the other hand, when customers want to build or renovate a house; it is difficult to find building materials and service providers in one system. Service providers will provide expertise in building and renovating homes based on customer demand. Based on this problem, researchers built a Project Service Information System that aims to facilitate customers, service providers, and suppliers in a system called eMarket place Si Jas Pro. Expected to be able to help and open business opportunities for small building material entrepreneurs and building service providers, make it easier for customers to buy material needs and find service providers, customers know the prices and material services so they can estimate their desired needs, customers can consult with building consultants, provide work sketches and provide comments on service provider work to improve customer service.

Keywords: Service Providers, e-Marketplace, customers.

Copyright @ 2019: This is an open-access article distributed under the terms of the Creative Commons Attribution license which permits unrestricted use, distribution, and reproduction in any medium for non-commercial use (NonCommercial, or CC-BY-NC) provided the original author and source are credited.

\section{INTRODUCTION}

The rapid development of information and communication technology at affordable prices makes the internet a major necessity in everyday life. The results of a data survey conducted by the Indonesian Internet Service Providers Association (APJII) In 2017 there were 143.26 million people in the number of internet users in Indonesia or 54.68 percent of
Indonesia's total population which reached 262 million people, an increase compared to 2016 which reached 132, 7 million people, this number is predicted to continue to grow. With smartphone prices get cheaper and telecommunications companies competing to improve the quality of the internet network to areas outside major cities in Indonesia [1].

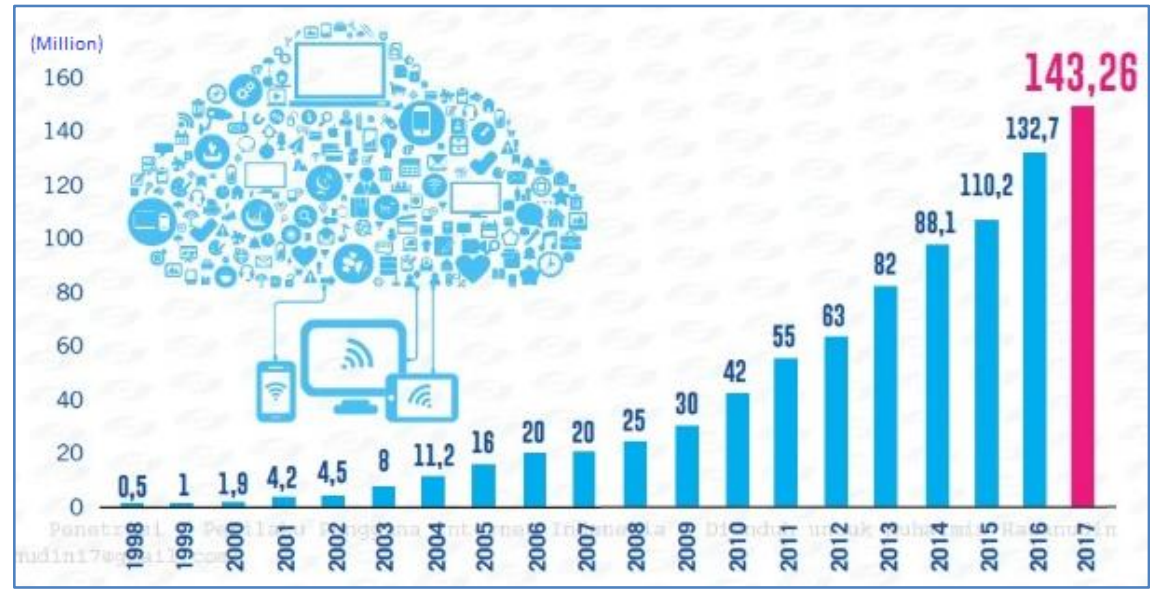

Fig-1: Internet User Statistics Data in Indonesia 1998-2017 
Muhaimin Hasanudin et al., Sch Bull, Nov 2019; 5(11): 635-638

In the industrial era 4.0 , it requires the readiness of consumers and service providers to use the latest information technology and innovation, many companies in Indonesia provide web-based or cellularbased services such as the transportation sector that gives users to order effectively and efficiently. Public transportation services namely Gojek and Grab. There are also services that bring together sellers and buyers of goods, namely Bukalapak, Tokopedia, there are also service providers, namely sejasa.com and tukang.com [2-5].

The rapid development of internet technology makes it easy for suppliers to promote and sell building materials to customers; customers can find the building materials needed $[9,11,12]$. However, there are problems in building or renovating homes when looking for materials and service providers (builders) in one system. Based on these problems, researchers made the design of Project Services Information System (Si JasPro) which is expected to bridge between material suppliers, builders as skill sellers. Consumers as buyers of building materials and provide tasks to service providers (builders) that can be accessed via laptops in one application called eMarketplace Si Jaspro

\section{e-MarketPlace}

Marketplace is an internet-based online media as a transactional container between customers, service providers and suppliers in one system [11, 13]. Customers can buy the needed materail and look for service providers to carry out the work of building or renovating homes. Service providers provide expertise services in building and renovating homes based on customer demand while suppliers can promote their merchandise.

Services are invisible products that are produced through the provision of facilities and infrastructure and are supported by certain skills or expertise from service providers to customers. Customer satisfaction is one of the success factors of the company by improving the quality of service to customers [14].

\section{Implementation of eMarketPlace Project Information System Services}

\begin{tabular}{|l|l|}
\hline Code & Description \\
\hline JAS01 & The application can register users as visitors, customers, service providers and suppliers \\
\hline JAS02 & The application is able to verify user registration \\
\hline JAS03 & Applications can make purchases of material, project services and payments \\
\hline JAS04 & The application can process data on building materials \\
\hline JAS05 & The application can process data both project service workers, craftsmen daily, kernek and wholesale \\
\hline JAS06 & Applications can provide discounts to customers according to applicable regulations. \\
\hline JAS07 & The application is able to verify customer purchase and payment transactions \\
\hline JAS08 & The application can process transaction cancellations \\
\hline JAS09 & The application can process comments, chat and email \\
\hline JAS10 & $\begin{array}{l}\text { Applications can process material shipments with goods delivery partners such as JNE, TIKI, Post and } \\
\text { others }\end{array}$ \\
\hline
\end{tabular}

\section{Software Requirements}

Software requirements are divided into two, namely functional requirements and non-functional requirements. Functional requirements are obtained through the study of literature about the marketplace.
To build this information system, it can be explained the system needs plan as shown in table 1 below.

From the functional requirements above, it can be mapped the actors involved directly in managing the system, as in table 2 below.

Table-2: System Entity

\begin{tabular}{|l|l|}
\hline Code & Description \\
\hline Administrator & $\begin{array}{l}\text { Si JasPro eMarketplace application manager can manage customer, supplier and service data } \\
\text { and can validate registration or purchase and payment. }\end{array}$ \\
\hline Customer & $\begin{array}{l}\text { Si JasPro eMarketplace application user who has an account and can purchase material and } \\
\text { service transactions as well as payments from the transaction results. }\end{array}$ \\
\hline Supplier & Building material stores that have accounts and sell and promote materials \\
\hline Service Provider & $\begin{array}{l}\text { Work partners who have an account and promote their expertise and experience in working on } \\
\text { home and building projects }\end{array}$ \\
\hline
\end{tabular}

\section{System Design}

Class diagram as a tool to define the types of entities that exist in the system and describe the relationship between one entity with another entity. The following is a description of the entities used in this study. 


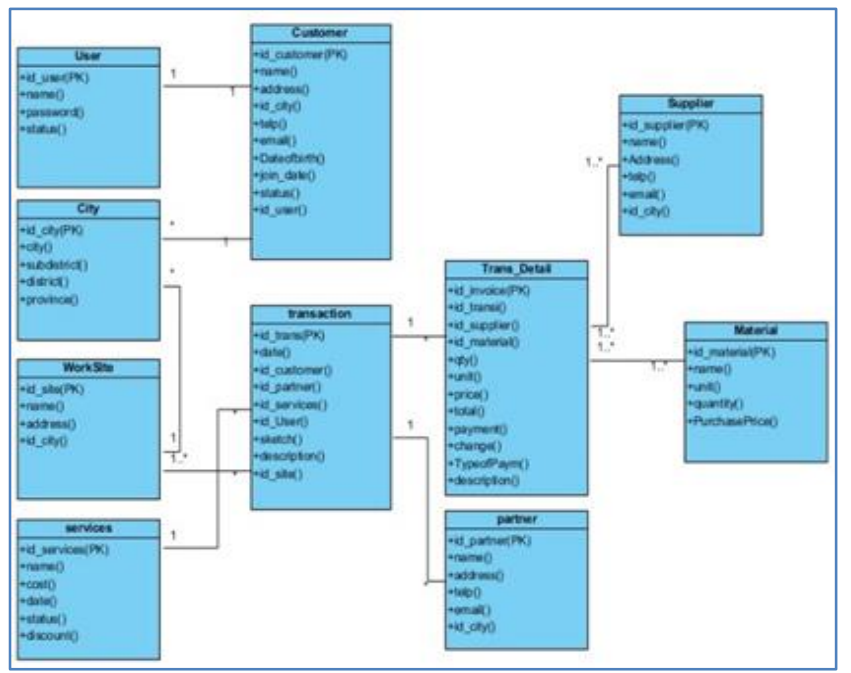

Fig-2: Class diagram of Sijaspro

\section{Construction}

The construction phase is the process of writing a coding program based on the PHP programming language and a MySql database application that is executed by a programmer based on the system analyst agreed by the system user. SiJasPro is an online business model that facilitates sellers in promoting their business, customers to look for building material needs and labor services, services providing labor services from the capabilities and expertise they have. In developing the system, the author uses Smarty as a php framework while the database uses Mysql. Smarty separates PHP from HTML which is used to generate HTML content dynamically by placing special tags in the document. A simple script from smarty can be seen below.

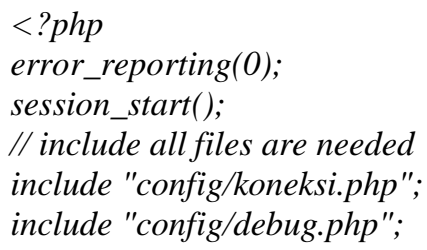

include "config/fungsi_rupiah.php"; include "config/fungsi_url.php"; include "config/fungsi_generate.php"; include "config/fungsi_halaman.php"; include "config/date_function.php"; require('libs/Smarty.class.php'); // create smarty new object

\$smarty = new Smarty;

$\$ i p=\$$ SERVER['REMOTE_ADDR'];

// set year for the website footer in the tpl

$\$$ year = date $\left({ }^{\prime} Y^{\prime}\right)$;

\$faktur = \$_SESSION['nofaktur'];

if(empty(\$faktur))

$\$$ faktur = date( $(y m$ mhis');

\$_SESSION['nofaktur'] = \$faktur; $\}$

\section{Interface System}

Implementation of the interface is a display of the application built; this application has several menu views such as displaying the latest products, best-selling products, freight forwarding services as seen in Figure 3.

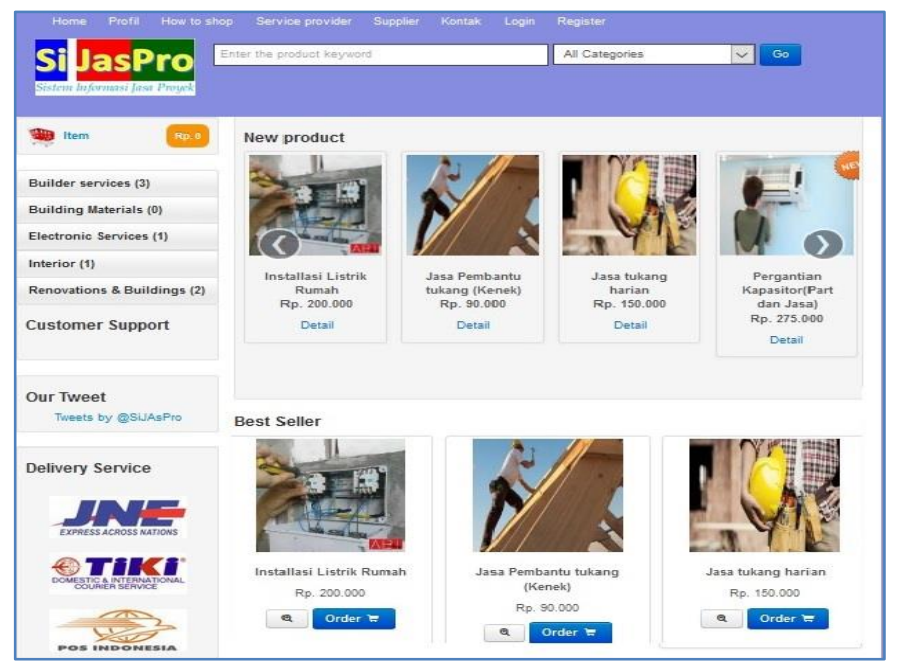

Fig-3: Si Jas Pro Application Menu 


\section{CONCLUSION}

Based on the discussion of the results of research conducted, it can be concluded that this application is designed as a means of providing information and transactions on building materials, building services in one system. Customers can buy building materials and obtain service providers for making renovations, services, making it easier for buyers to obtain information on the products they want to buy, service providers can offer work services and sellers can promote their products through this website as intermediaries to buyers so that it is hoped that a transaction or communication media can be created which is good for sellers, business partners and buyers in one container.

\section{REFERENCES}

1. Indonesia, A. P. J. I. (2016). Penetrasi \& Perilaku Pengguna Internet Indonesia.

2. Prihastomo, Y., Hidayanto, A. N., \& Prabowo, H. (2018, September). The Key Success Factors in EMarketplace Implementation: A Systematic Literature Review. In 2018 International Conference on Information Management and Technology (ICIMTech) (pp. 443-448). IEEE.

3. Porntrakoon, P., \& Moemeng, C. (2017, June). A model for multi-dimensional trust measurement in thailand e-marketplace. In 2017 14th International Conference on Electrical Engineering/Electronics, Computer, Telecommunications and Information Technology (ECTI-CON) (pp. 73-76). IEEE.

4. Hasanudin, M. (2019). Aplikasi e-commerce sistem informasi penjualan rolling door berbasis rapid application development. PETIR, 12(1).

5. Prihastomo, Y., Hidayanto, A. N., \& Prabowo, H. (2018, September). The Key Success Factors in EMarketplace Implementation: A Systematic Literature Review. In 2018 International Conference on Information Management and Technology (ICIMTech) (pp. 443-448). IEEE.

6. Filman, R., Elrad, T., Clarke, S., \& Akşit, M. (2004). Aspect-oriented software development. Addison-Wesley Professional.

7. Vishal, P., \& Bhattacharya, S. (2013). Application of the Pareto principle in rapid application development model.
8. Iguider, Y., \& Morita, H. (2011, March). A collective intelligence based business-matching and recommending system for next generation emarketplaces. In 2011 IEEE Symposium on Computers \& Informatics (pp. 489-494). IEEE.

9. Umar, R., Fahana, J., \& Triyono, A. (2018, October). Development of E-Marketplace in Department of Agriculture Food Crops and Horticulture as a Means to Expand The Market of Processed Food. In 2018 12th International Conference on Telecommunication Systems, Services, and Applications (TSSA) (pp. 1-4). IEEE.

10. Patel, A., Qi, W., \& Wills, C. (2010). A review and future research directions of secure and trustworthy mobile agent-based e-marketplace systems. Information Management \& Computer Security, 18(3), 144-161.

11. Apriadi, D., \& Saputra, A. Y. (2017). E-Commerce Berbasis Marketplace Dalam Upaya Mempersingkat Distribusi Penjualan Hasil Pertanian. Jurnal RESTI (Rekayasa Sistem dan Teknologi Informasi), 1(2), 131-136.

12. Umar, R., Fahana, J., \& Triyono, A. (2018, October). Development of E-Marketplace in Department of Agriculture Food Crops and Horticulture as a Means to Expand The Market of Processed Food. In 2018 12th International Conference on Telecommunication Systems, Services, and Applications (TSSA) (pp. 1-4). IEEE.

13. Kurniasary, E., Mukhtar, M., Jailani, N., Abdullah, S., Yahya, Y., \& Abdullah, Z. (2008, August). Designing an e-marketplace prototype for woodbased product industry in Malaysia: A concept that fits reality. In 2008 International Symposium on Information Technology (Vol. 1, pp. 1-7). IEEE.

14. Olorunniwo, F., Hsu, M. K., \& Udo, G. J. (2006). Service quality, customer satisfaction, and behavioral intentions in the service factory. Journal of services marketing, 20(1), 59-72.

15. Jahanshahi, A. A., Gashti, M. A. H., Mirdamadi, S. A., Nawaser, K., \& Khaksar, S. M. S. (2011). Study the effects of customer service and product quality on customer satisfaction and loyalty. International Journal of Humanities and Social Science, 1(7), 253-260. 